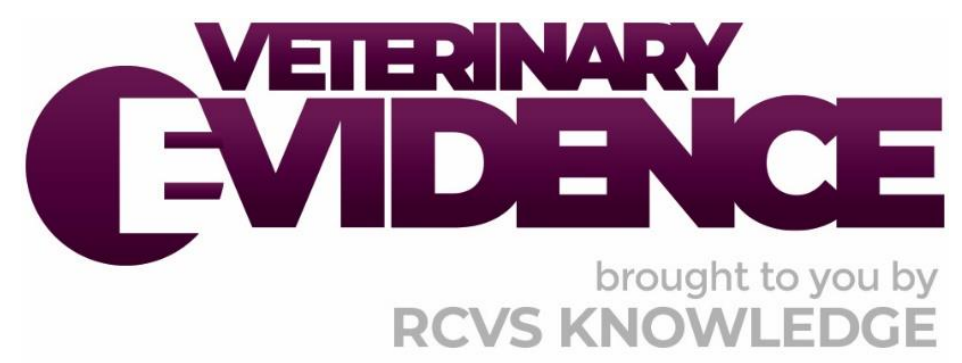

\title{
Non-Steroidal Anti-inflammatories: Does carprofen or meloxicam have fewer gastrointestinal side effects?
}

\section{A Knowledge Summary by}

Aaron Fletcher BVetMed MRCVS ${ }^{1 *}$

\footnotetext{
${ }^{1}$ Heath Lodge Veterinary Group, St Bernard's Road, St Albans, Hertfordshire, AL3 5RA

*Corresponding Author (afletcher53@gmail.com)
}

ISSN: 2396-9776

Published: 11 Sep 2020

in: The Veterinary Evidence journal Vol 5, Issue 3

DOI: 10.18849/VE.V5I3.301

Reviewed by: James Swann (MA VetMB DACVIM DECVIM

MRCVS) and Edward Hall (MA VetMB PhD

DipECVIM-CA FRCVS)

Next Review Date: 30 Oct 2021 


\section{KNOWLEDGE SUMMARY}

\section{PICO question}

In canines, does the oral administration of carprofen, when compared to meloxicam, result in fewer gastrointestinal side effects?

\section{Clinical bottom line}

\section{Category of research question}

Treatment

\section{The number and type of study designs reviewed}

Three prospective randomised controlled trials were critically reviewed

\section{Strength of evidence}

\section{Weak}

\section{Outcomes reported}

Treatment with carprofen or meloxicam results in no significant difference in gastric lesion scoring, increased intestinal mucosal permeability or diminished small bowel absorptive capacity

\section{Conclusion}

There is insufficient evidence supporting preferential administration of carprofen or meloxicam to reduce gastrointestinal side effects

\section{How to apply this evidence in practice}

The application of evidence into practice should take into account multiple factors, not limited to: individual clinical expertise, patient's circumstances and owners' values, country, location or clinic where you work, the individual case in front of you, the availability of therapies and resources.

Knowledge Summaries are a resource to help reinforce or inform decision-making. They do not override the responsibility or judgement of the practitioner to do what is best for the animal in their care

\section{Clinical Scenario}

You wish to prescribe non-steroidal anti-inflammatory drugs (NSAIDs) to a canine patient with arthritic pain. The patient has no contraindications for prescribing an NSAID and has not been prescribed an NSAID before. The owner is concerned about gastrointestinal side effects of NSAIDS and you wish to find out if there is a scientific basis for the preferential treatment with carprofen or meloxicam for this. 


\section{The evidence}

Three prospective randomised controlled studies have been found which are partially relevant to the PICO (Luna et al., 2007; Craven et al., 2007; and Forsyth et al., 1998).

Two of the randomised controlled trials studied the effects of carprofen or meloxicam administration on gastrointestinal adverse reactions. Both these trials used endoscopic measured gastric mucosal lesion scoring following oral NSAID administration (Forsyth et al., 1998; and Luna et al., 2007) and in addition one of the trials measured an outcome of faecal occult blood (Luna et al. 2007). One randomised controlled trial measured the effects of carprofen or meloxicam administration on the gastric permeability and mucosal absorptive capacity through sugar solution absorption (Craven et al., 2007).

The strength of the evidence found was very weak for the PICO question, and there is insufficient evidence to recommend treatment with either carprofen or meloxicam to limit the frequency of gastrointestinal side effects.

\section{Summary of the evidence}

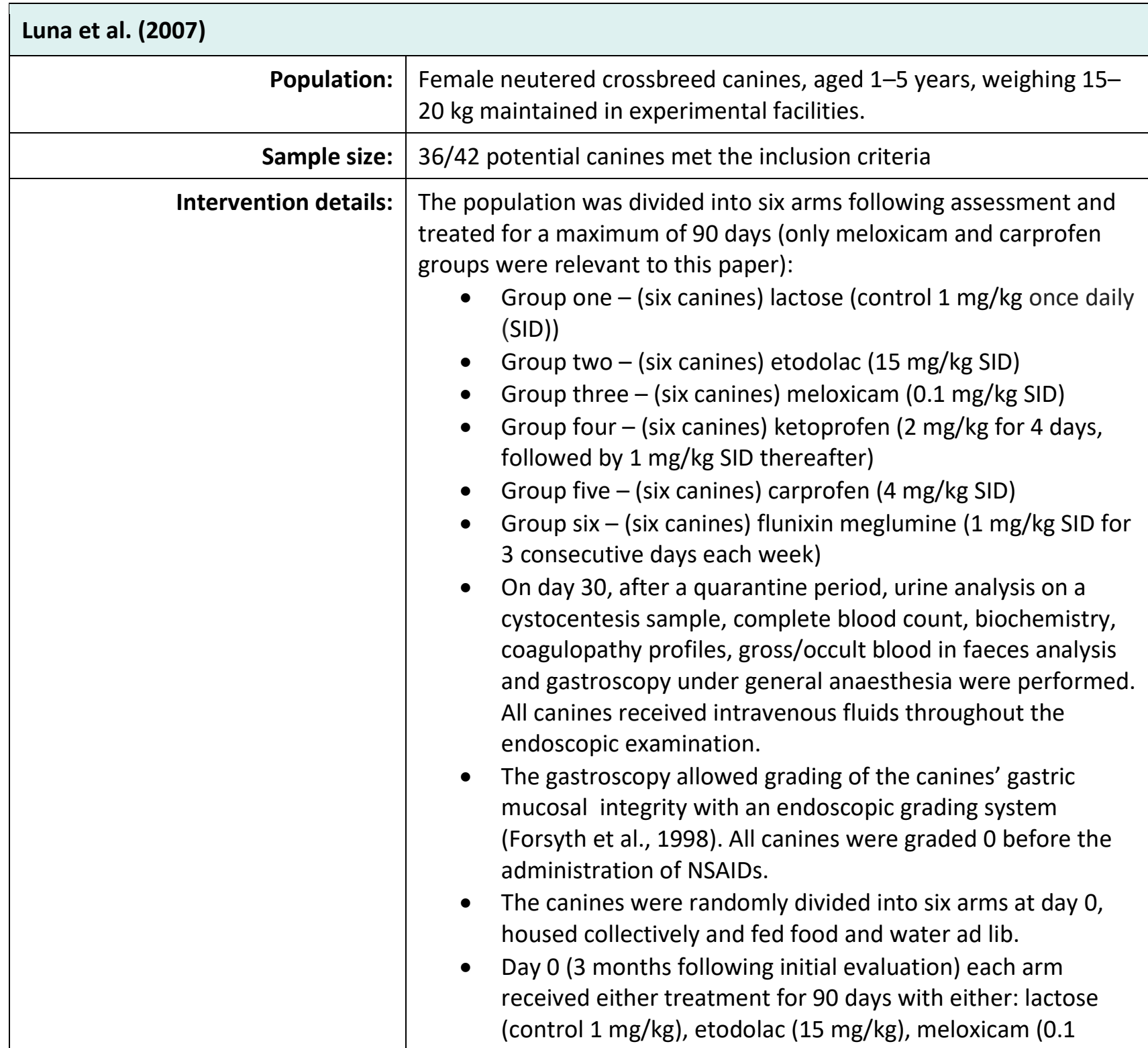




\begin{tabular}{|c|c|}
\hline & $\begin{array}{l}\mathrm{mg} / \mathrm{kg} \text { ), ketoprofen ( } 2 \mathrm{mg} / \mathrm{kg} \text { for } 4 \text { days, followed by } 1 \\
\mathrm{mg} / \mathrm{kg} / \mathrm{d} \text { thereafter), carprofen ( } 4 \mathrm{mg} / \mathrm{kg} \text { ) or flunixin } \\
\text { meglumine (1 mg/kg for } 3 \text { consecutive days each week). } \\
\text { A veterinarian performed a general health check daily for } \\
\text { any abnormalities. If there were any abnormal clinical } \\
\text { findings, the animal underwent a complete clinical and } \\
\text { laboratory examination. Each animal was then assessed by } \\
\text { an investigator, who was blinded to the treatment group. If } \\
\text { that investigator deemed the abnormal findings were a } \\
\text { result of the administration of the NSAID, the animal was } \\
\text { excluded. } \\
\text { All animals underwent a complete examination, including } \\
\text { clinical and laboratory tests on days } 7,30,60,90 \text {. } \\
\text { Veterinarians performing gastroscopies were unaware of the } \\
\text { treatments received by the canines. }\end{array}$ \\
\hline Study design: & A prospective randomised controlled trial \\
\hline Outcome studied: & $\begin{array}{l}\text { Gastric mucosal lesion grading after } 90 \text { days of treatment. } \\
\text { Occult faecal blood test after } 90 \text { days of treatment. }\end{array}$ \\
\hline $\begin{array}{l}\text { Main findings: } \\
\text { (relevant to PICO question): }\end{array}$ & $\begin{array}{l}\text { Gastric lesion grading is based on the following scale (higher being } \\
\text { worse): } \\
\text { - Grade } 0 \text { (no visible haemorrhages, erosions, or ulcers) } \\
\text { - Grade } 1 \text { ( } 1 \text { to } 5 \text { punctate erosions, haemorrhages, or both) } \\
\text { - Grade } 2 \text { ( } 6 \text { to } 15 \text { punctate erosions, haemorrhages, or both) } \\
\text { - Grade } 3 \text { (16 to } 25 \text { punctate erosions, haemorrhages, or } \\
\text { - Grade } 4 \text { (> } 25 \text { punctate erosions, haemorrhages, or both; } 1 \\
\text { - to } 5 \text { invasive erosions; or both) } \\
\text { - Grade } 5 \text { (> } 6 \text { invasive erosions) } \\
\text { Meloxicam treatment arm } \\
\text { - Gastric lesions recorded after } 90 \text { days of treatment: } \\
\quad 0 \quad \text { Grade } 4 \text { (two canines) } \\
\circ \quad \text { Grade } 0 \text { (four canines) } \\
\text { - The proportion of positive occult faecal blood test after } 90 \\
\text { days of treatment: } 5 / 6 \\
\text { Carprofen treatment arm } \\
\text { - Gastric lesions recorded in the carprofen arm after } 90 \text { days } \\
\text { of treatment: } \\
\quad 0 \quad \text { Grade } 5 \text { (one canine) } \\
\circ \quad \text { Grade } 0 \text { (five canines) } \\
\text { - The proportion with positive occult faecal blood test after } 90 \\
\text { days of treatment: } 3 / 6\end{array}$ \\
\hline Limitations: & $\begin{array}{l}\text { - Not a crossover study, so cannot eliminate variability of } \\
\text { reaction to different NSAIDs. } \\
\text { - The method of randomisation was not stated. } \\
\text { - The paper did not explicitly state that the veterinarian } \\
\text { assessing the animal was blinded to the study aims. } \\
\text { Very small arm sizes were used with no sample size } \\
\text { calculation provided. }\end{array}$ \\
\hline
\end{tabular}




\begin{tabular}{|l|l|}
\hline - & Large study dropout rate (14.2\%), and active exclusion of \\
& four patients (9.2\%) with adverse effects deemed from \\
& NSAID administration (although not from the carprofen or \\
meloxicam groups). & NSAID doses did not follow the licensed dosage for common \\
preparations, e.g. Metacam (meloxicam) is recommended at \\
an initial $0.2 \mathrm{mg} / \mathrm{kg}$ dose on day 1, subsequently reduced to \\
$0.1 \mathrm{mg} / \mathrm{kg}$ on day 2 and Rimadyl (carprofen) is \\
recommended at an initial $2-4 \mathrm{mg} / \mathrm{kg}$ dose for the first 7 \\
days then a reduction to $2 \mathrm{mg} / \mathrm{kg}$. \\
The faecal occult blood test result can be influenced by \\
numerous factors, such as different diet (Rice \& Ihle, 1994).
\end{tabular}

Craven et al. (2007)

\begin{tabular}{|c|c|}
\hline Population: & $\begin{array}{l}\text { Canines from a client-owned referral population, with no signs of } \\
\text { gastrointestinal or renal disease. No azotaemia as determined up to } \\
7 \text { days before inclusion. No NSAID or corticosteroid administration } \\
\text { during the preceding } 8 \text { weeks. }\end{array}$ \\
\hline Sample size: & $\begin{array}{l}23 \text { adult canines, with a total of } 11 \text { different breeds: } \\
\text { - } 13 \text { females, nine neutered } \\
\text { - } 10 \text { males, seven neutered. } \\
\text { Three canines were withdrawn due to vomiting. }\end{array}$ \\
\hline Intervention details: & $\begin{array}{l}\text { The population was divided into two groups: } \\
\text { - Group M ( } 10 \text { canines) - Administered meloxicam orally } 0.2 \\
\text { mg/kg on day } 1 \text {, and } 0.1 \mathrm{mg} / \mathrm{kg} \text { subsequently SID } \\
\text { - Group C ( } 10 \text { canines) - Administered carprofen orally } 4 \\
\text { mg/kg on day } 1 \text {, and } 2 \mathrm{mg} / \mathrm{kg} \text { subsequently SID. } \\
\text { A permeability test was administered to the subjects: } \\
\text { - Six sugars; sucrose, lactulose, rhamnose, D-xylose, 3-O- } \\
\text { methyl-d-glucose and sucralose formed a sugar solution } \\
\text { which was administered to each subject. } \\
\text { - The sugars are absorbed in different parts of the intestine. } \\
\text { Canines }>20 \text { kg received } 400 \text { ml, canines } 10-20 \text { kg received } \\
200 \text { ml and canines }<10 \text { kg } 100 \text { ml of the sugar solution. } \\
\text { - After a } 12 \text { hour fast, sterile urethral catheterisation and } \\
\text { aliquots of urine were stored in sodium azide. } \\
\text { - For any canines not drinking the sugar solution, it was } \\
\text { administered with a } 10 \text { Fr oroesophageal tube. } \\
\text { - After } 6 \text { hours, the bladder was emptied via sterile urethral } \\
\text { catheterisation, and all urine collected during the test period } \\
\text { was mixed. } \\
\text { - All sugars, except sucralose, were analysed by high pressure } \\
\text { liquid chromatography at an external laboratory. } \\
\text { - Sucralose was measured by capillary column gas } \\
\text { chromatography at the Rush University Medical Center, } \\
\text { Chicago, Illinois. } \\
\text { - A permeability test was performed before NSAID therapy on } \\
\text { day } 1 \text { (before NSAID), day } 3 \text { and } 8 \text {. }\end{array}$ \\
\hline
\end{tabular}




\begin{tabular}{|c|c|}
\hline & $\begin{array}{l}\text { - NSAIDs were administered within } 24 \text { hours of performing } \\
\text { the first permeability test. }\end{array}$ \\
\hline Study design: & A prospective randomised controlled trial \\
\hline Outcome studied: & $\begin{array}{l}\text { Objective measurements of urinary; } \\
\text { - sucrose concentration ( } \mathrm{S}) \text {, } \\
\text { - } \text { sucralose concentration (SU), } \\
\text { - measure of small intestinal permeability), } \\
\text { - and the ratio of D-xylose: } 3-O \text {-methyl-d-glucose (X:M is a } \\
\text { measure of carbohydrate absorption). }\end{array}$ \\
\hline $\begin{array}{l}\text { Main findings: } \\
\text { (relevant to PICO question): }\end{array}$ & $\begin{array}{l}\text { Sucrose is digested as it enters the small intestine, so permeation } \\
\text { and urinary excretion is considered to reflect gastric permeability. } \\
\text { Sucralose recovery is considered an indirect marker of colonic } \\
\text { permeability. } \\
\text { - Group } M \text { - No significant changes in urinary concentrations } \\
\text { of } S, \mathrm{Sl} \text {, or L:R or } \mathrm{X}: \mathrm{M} \text { ratios at any time. } \\
\text { - Group C - Urinary S recovery significantly decreased } \\
\text { between day } 1 \text { and } 3(\mathrm{P}=0.049) \text {, significantly increased } \\
\text { between day } 3 \text { to } 8 \text { ( } \mathrm{P}=0.049) \text { but the increase was not } \\
\text { significantly different to the level before treatment ( } \mathrm{P}= \\
\text { 0.695). This was thought to be caused by a decreased gastric } \\
\text { permeability. Urinary recovery of SU, L: R and X: M did not } \\
\text { significantly differ. } \\
\text { The difference in sucrose recovery on day 3, between groups } \\
\text { C and M, might indicate changes in gastric permeability. } \\
\text { No significantly increased intestinal mucosal permeability or } \\
\text { diminished small bowel absorptive capacity in canines receiving } \\
\text { standard doses of carprofen or meloxicam in the acute phase. }\end{array}$ \\
\hline Limitations: & $\begin{array}{l}\text { Very small arm sizes were used with no sample size } \\
\text { calculation provided } \\
\text { - Large study dropout, reducing the validity of statistical } \\
\text { results. } \\
\text { - Limited evidence showing that sugar absorption deficiency } \\
\text { correlates to gastrointestinal side effects. Current evidence } \\
\text { is based on human medicine only. }\end{array}$ \\
\hline
\end{tabular}

\begin{tabular}{|c|c|}
\hline \\
\hline \multicolumn{2}{|c|}{\begin{tabular}{l|l} 
Population: & $\begin{array}{l}\text { Mixed-breed colony canines housed in groups of eight, aged 1-12 } \\
\text { years old. }\end{array}$
\end{tabular}} \\
\hline Sample size: & 24 canines \\
\hline Intervention details: & $\begin{array}{l}\text { Canines were randomly assigned to four treatment groups (6 } \\
\text { canines per group): } \\
\text { - Group one received oral carprofen } 2 \mathrm{mg} / \mathrm{kg} \text { BID for } 7 \text { days, } \\
\text { then } 2 \mathrm{mg} / \mathrm{kg} \text { SID. } \\
\text { - Group two received oral meloxicam } 0.2 \mathrm{mg} / \mathrm{kg} \text { SID. } \\
\text { - Group three received oral ketoprofen } 1 \mathrm{mg} / \mathrm{kg} \text { SID. }\end{array}$ \\
\hline
\end{tabular}




\begin{tabular}{|c|c|}
\hline & $\begin{array}{l}\text { - Group four received oral placebo (gelatine) capsule (one } \\
\text { capsule daily). } \\
\text { Each canine underwent anaesthesia for gastric endoscopy } 7 \\
\text { days before the start of the study, to assess for evidence of } \\
\text { grossly visible lesions. } \\
\text { - Examination of the oesophagus through to the duodenum } \\
\text { occurred, which was videotaped. } \\
\text { - The number of lesions, type of lesion, presence of blood, } \\
\text { presence of mucosal granularity and size of the lesions at } \\
\text { each site was recorded and graded. } \\
\text { - Repeat endoscopic examination and grading was performed } \\
\text { on days } 7 \text { and } 28 \text {. The endoscopist recording the results was } \\
\text { blinded to the treatment group. }\end{array}$ \\
\hline Study design: & A prospective randomised controlled trial \\
\hline Outcome studied: & $\begin{array}{l}\text { The subjective mucosal grading scale of the oesophagus, gastric } \\
\text { cardia/fundus, stomach body, body/antrum junction, antrum and } \\
\text { duodenum. }\end{array}$ \\
\hline $\begin{array}{l}\text { Main findings: } \\
\text { (relevant to PICO question): }\end{array}$ & $\begin{array}{l}\text { No significant difference between the gastric lesion scores between } \\
\text { the NSAID groups (1-3) and the gelatine group (4). }\end{array}$ \\
\hline Limitations: & $\begin{array}{l}\text { - Very small arm sizes were used with no sample size } \\
\text { calculation provided. } \\
\text { - Some canines had gastric lesions before the treatment was } \\
\text { given. Interestingly, canines treated with ketoprofen had the } \\
\text { highest frequency of pre-existing gastric lesions before } \\
\text { NSAID administration and had a higher number of gastric } \\
\text { lesions at day 28. Could the canines have other unaccounted } \\
\text { for diseases which caused this? } \\
\text { - There was no description of clinical signs. } \\
\text { - Method of randomisation not stated. }\end{array}$ \\
\hline
\end{tabular}

\section{Appraisal, application and reflection}

Three prospective randomised controlled trials have been found which provide partially relevant evidence to compare the gastrointestinal side effects of meloxicam and carprofen (Luna et al., 2007; Craven et al., 2007; and Forsyth et al., 1998).

The outcomes measured in the research varied. There was one weak piece of research which supported no statistically significant difference in gastric mucosal lesion scoring between carprofen and meloxicam treatment (Forsyth et al., 1998), while one weak non-statistically backed piece of research reported that carprofen had lower gastric mucosal lesion scoring than meloxicam (Luna et al., 2007). One weak piece of research reported no statistically significant difference in gastric permeability in canines receiving standard doses of carprofen or meloxicam in the acute phase (Craven et al., 2007).

While two of the studies measured an objective outcome occult faecal blood or sugar permeability testing, none of the studies measurable outcomes have been correlated to an increased frequency of the common gastrointestinal side effects (Craven et al., 2007; and Luna et al., 2007). What is more, in these studies, subjects were excluded if they developed commonly outwardly detectable gastrointestinal signs. As $38 \%$ of research studies report adverse effects from NSAID administration, actively excluding patients who show these reduces the evidence relevancy to the PICO question (Monteiro-Steagall et al., 2013). 
The clinical relevance of the outcomes recorded are debatable as they differ from the common gastrointestinal side effects reported in practice following NSAID treatment (vomiting, diarrhoea, anorexia, lethargy and melaena (Monteiro-Steagall et al., 2013)). Even more, gastric endoscopy, and sugar absorption are not commonly used techniques to assess gastrointestinal side effects in first opinion practice.

The limitations of all three studies reduce the strength of the presented evidence, with some experimental design issues.

In human medicine, there is marked variability in an individual's reaction to NSAIDs (Bruno et al., 2014). Interestingly, the literature search found no crossover studies for the two NSAIDS in this PICO question, which are two of the most frequently prescribed NSAIDS. Crossover studies would be an appropriate study design to assess the side effects of NSAIDS, and would reduce the impact of any individual drug reactions.

No study provided power calculations for the populations they used, or confidence intervals for outcomes measured. This increases the risks of Type 1 and Type 2 errors when assessing the evidence and further diminishes its strength (Banerjee et al., 2009).

The NSAID dose and duration administered to the subjects received varied widely between studies.

Craven et al. (2007) dosed carprofen according to the product datasheet and used a licensed form in the United Kingdom ( $4 \mathrm{mg} / \mathrm{kg} / \mathrm{d}$ day 1 and 2 then $2 \mathrm{mg} / \mathrm{kg} / \mathrm{d}$ subsequently, Rimadyl). Luna et al. (2007) exceeded the long-term maintenance dose of their carprofen preparation but used a licensed form in the United Kingdom (4 mg/kg/d, Rimadyl). Forsyth et al. (1998) used a preparation which is unlicensed for use in the United Kingdom (Zenecarp, $2 \mathrm{mg} / \mathrm{kg}$ BID 7 days, then $2 \mathrm{mg} / \mathrm{kg} / \mathrm{d}$ for 7 days). In contrast, the dosage of meloxicam, while still variable, was more consistent. Forsyth et al. (1998) administered meloxicam at 0.2 $\mathrm{mg} / \mathrm{kg} / \mathrm{d}$ (exceeding the current United Kingdom datasheet for Metacam by $0.1 \mathrm{mg} / \mathrm{d}$ for ongoing usage). Luna et al. (2007) administered meloxicam at $0.1 \mathrm{mg} / \mathrm{kg}$ ongoing (and did not increase the dose on day 1 as the current United Kingdom datasheet for Metacam suggests). Only Craven et al. (2007) followed the datasheet guidelines and administered meloxicam at $0.2 \mathrm{mg} / \mathrm{kg} / \mathrm{d}$ on day 1 and $0.1 \mathrm{mg} / \mathrm{kg} / \mathrm{d}$ subsequently. While the importance of these variations is not known, it does hinder meaningful clinical comparison as the doses given rarely matched the licensed dosages.

There has been an attempt to classify what defines an adverse effect in a systematic review, as 'outwardly detectable signs' that are assessed through observational monitoring, physical examination and non-invasive procedures (Monteiro-Steagall et al., 2013). These are inherently subjective criteria, but have much greater clinical relevance than the outcomes reported by this Knowledge Summary, and hence the systematic review may be more helpful for clinicians than this Knowledge Summary. Another limitation of this Knowledge Summary is that as some research found in the literature search did not report any adverse effects, it could have introduced reporting bias, by only including research studies which reported adverse events. Also, the inclusion criteria were for primary research which contained both drugs in the PICO question, excluding research for each of these drugs in isolation. The justification for this approach was an existing systematic review on evidence for the adverse effects of NSAIDs in veterinary medicine (Monteiro-Steagall et al., 2013), and that a Knowledge Summary of available comparator research would be more externally valid to the PICO question. The systematic review concluded that whilst there was high strength research available for carprofen and meloxicam, the strength of evidence regarding adverse drug experience was variable. Finally, a language bias may have been introduced by only selecting papers that were published in English.

Despite these limitations, this Knowledge Summary is the first comparator looking to assess gastrointestinal side effects of these two frequently used NSAIDs. NSAIDs are a widely used analgaesic in veterinary medicine, and while there is high strength evidence documenting for the adverse effects of these drugs (MonteiroSteagall et al., 2013), there is a lack in comparative research to guide rational clinical decision making between products. This Knowledge Summary concluded that there is insufficient evidence to recommend treatment with meloxicam over carprofen to reduce the frequency of gastrointestinal side effects. 


\section{Methodology Section}

\begin{tabular}{|c|c|}
\hline \multicolumn{2}{|l|}{ Search Strategy } \\
\hline $\begin{array}{r}\text { Databases searched and dates } \\
\text { covered: }\end{array}$ & $\begin{array}{l}\text { CAB Abstracts 1900-2019 } \\
\text { Pubmed 1910-2019 } \\
\text { Web of Science 1900-2019 }\end{array}$ \\
\hline Search terms: & $\begin{array}{l}\text { CAB Abstracts - (canin* or dog* or dog) AND (adverse* or side* or } \\
\text { safety*) AND meloxicam AND carprofen } \\
\text { Pubmed - (canin* or dog* or dog) AND ("adverse*" or "side*" or } \\
\text { "safety*") AND carprofen AND meloxicam } \\
\text { Web of Science - (TS=((canin* or dog* or dog) and (adverse* or } \\
\text { side* or safety*) and carprofen and meloxicam)) }\end{array}$ \\
\hline Dates searches performed: & 30 Oct 2019 \\
\hline
\end{tabular}

\section{Exclusion / Inclusion Criteria}

\begin{tabular}{l|l} 
Exclusion: & $\begin{array}{l}\text { Papers not in English } \\
\text { Paper cannot be accessed } \\
\text { The study: } \\
-\quad \text { was not relevant to the PICO } \\
-\quad \text { did not contain the two non-steroidal anti-inflammatories } \\
-\quad \text { did not consider gastrointestinal adverse effects } \\
\text { - } \text { inSAID treatment arm also included other COX enzyme } \\
\text { - } \quad \text { sequential administration of NSAIDs without washout } \\
\text { Reviews } \\
\text { Single case reports } \\
\text { Conference papers } \\
\text { Book chapters }\end{array}$ \\
Inclusion: & $\begin{array}{l}\text { Any relevant primary research paper which compared the } \\
\text { gastrointestinal side effects of the non-steroidal anti- } \\
\text { inflammatories, carprofen and meloxicam. }\end{array}$
\end{tabular}




\begin{tabular}{|c|c|c|c|c|c|c|}
\hline \multicolumn{7}{|c|}{ Search Outcome } \\
\hline Database & $\begin{array}{l}\text { Number } \\
\text { of } \\
\text { results }\end{array}$ & $\begin{array}{l}\text { Excluded-Case } \\
\text { reports, } \\
\text { conference } \\
\text { papers, } \\
\text { reviews, book } \\
\text { chapters, } \\
\text { correspondence }\end{array}$ & $\begin{array}{c}\text { Excluded - } \\
\text { Not relevant } \\
\text { to PICO }\end{array}$ & $\begin{array}{c}\text { Excluded - } \\
\text { Languages } \\
\text { other than } \\
\text { English }\end{array}$ & $\begin{array}{l}\text { Excluded - } \\
\text { Inaccessible }\end{array}$ & $\begin{array}{c}\text { Total } \\
\text { relevant } \\
\text { papers }\end{array}$ \\
\hline $\begin{array}{l}\text { CAB } \\
\text { Abstracts }\end{array}$ & 36 & 14 & 12 & 4 & 3 & 3 \\
\hline PubMed & 13 & 3 & 7 & 0 & 1 & 2 \\
\hline $\begin{array}{l}\text { Web of } \\
\text { Science }\end{array}$ & 73 & 16 & 55 & 0 & 0 & 2 \\
\hline \multicolumn{6}{|c|}{ Total relevant papers when duplicates removed } & 3 \\
\hline
\end{tabular}

\section{CONFLICT OF INTEREST}

The author declares no conflicts of interest.

\section{REFERENCES}

1. Banerjee, A., Chitnis, U. B., Jadhav, S. L., Bhawalkar, J. S., \& Chaudhury, S. (2009). Hypothesis testing, type I and type II errors. Industrial Psychiatry Journal, 18(2), 127-

131. DOI: https://doi.org/10.4103/0972-6748.62274

2. Bruno, A., Tacconelli, S. \& Patrignani, P. (2014). Variability in the response to non-steroidal antiinflammatory drugs: Mechanisms and perspectives. Basic and Clinical Pharmacology and Toxicology, 114(1). DOI: http://dx.doi.org/10.1111/bcpt.12117

3. Craven, M., Chandler, M. L., Steiner, J. M., Farhadi, A., Welsh, E., Pratschke, K., Shaw, D. J., \& Williams, D. A. (2007). Acute effects of carprofen and meloxicam on canine gastrointestinal permeability and mucosal absorptive capacity. Journal of Veterinary Internal Medicine, 21(5), 917-

23. DOI: http://dx.doi.org/10.1111/j.1939-1676.2007.tb03043.x

4. Forsyth, S. F., Guilford, W. G., Haslett, S. J., \& Godfrey, J. (1998). Endoscopy of the gastroduodenal mucosa after carprofen, meloxicam and ketoprofen administration in dogs. Journal of Small Animal Practice, 39(9), 421-424. DOI: http://dx.doi.org/10.1111/j.1748-5827.1998.tb03748.x

5. Fox, S.M. \& Johnston, S.A. (1997). Use of carprofen for the treatment of pain and inflammation in dogs. Journal of the American Veterinary Medical Association, 210, 1493-8. 
6. Innes, J., Clayton, J. \& Lascelles, D. (2010). Long-term NSAID use for canine OA: is it more effective? Proceedings, 3rd World Veterinary Orthopaedic Congress, ESVOT-VOS, 15th ESVOT Congress, Bologna, Italy, 15-18 September, 341-342.

7. Luna, S. P., Basílio, A. C., Steagall, P. V., Machado, L. P., Moutinho, F. Q., Takahira, R. K., \& Brandão, C. V. (2007). Evaluation of adverse effects of long-term oral administration of carprofen, etodolac, flunixin meglumine, ketoprofen, and meloxicam in dogs. American Journal of Veterinary Research, 68(3), 258-264. DOI: http://dx.doi.org/10.2460/ajvr.68.3.258

8. Monteiro-Steagall, B.P., Steagall, P.V.M. \& Lascelles, B.D.X. (2013). Systematic review of nonsteroidal anti-inflammatory drug-induced adverse effects in dogs. Journal of Veterinary Internal Medicine, 27(5), 1011-1019. DOI: http://dx.doi.org/10.1111/jvim.12127

9. Pigott, J., Cobb, M. \& O'Rourke, D. (2015). A comprehensive review of adverse events associated with non-steroidal anti-inflammatory drug treatments in dogs in the UK. BSAVA Congress 2015: Scientific Proceedings, Birmingham, UK, 9-12 April 2015. DOI: http://dx.doi.org/10.22233/9781910443521.70.12

10. Rice, J.E. \& Ihle, S.L. (1994). Effects of diet on fecal occult blood testing in healthy dogs. Canadian Journal of Veterinary Research = Revue canadienne de recherche vétérinaire, 58(2), 134-137.

11. Valencia Sánchez, F., Gutiérrez Pérez, E. \& Pérez Carral, V. (2008). Calcinosis cutis en iguana. Argos: Informativo Veterinario, 58-60. 


\section{EVIIDEFeE

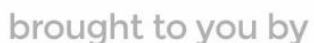 \\ RCVS KNOWLEDGE}

\section{Intellectual Property Rights}

Authors of Knowledge Summaries submitted to RCVS Knowledge for publication will retain copyright in their work, and will be required to grant RCVS Knowledge a non-exclusive license of the rights of copyright in the materials including but not limited to the right to publish, re-

publish, transmit, sell, distribute and otherwise use the materials in all languages and all media throughout the world, and to license or permit others to do so.

\section{Disclaimer}

Knowledge Summaries are a peer-reviewed article type which aims to answer a clinical question based on the best available current evidence. It does not override the responsibility

of the practitioner. Informed decisions should be made by considering such factors as individual clinical expertise and judgement along with patient's circumstances and owners' values. Knowledge Summaries are a resource to help inform and any opinions expressed within the Knowledge Summaries are the author's own and do not necessarily reflect the view of the RCVS Knowledge. Authors are responsible for the accuracy of the content. While the

Editor and Publisher believe that all content herein are in accord with current recommendations and practice at the time of publication, they accept no legal responsibility

for any errors or omissions, and make no warranty, express or implied, with respect to material contained within.

For further information please refer to our Terms of Use.

RCVS Knowledge is the independent charity associated with the Royal College of Veterinary Surgeons (RCVS). Our ambition is to become a global intermediary for evidence based veterinary knowledge by providing access to information

that is of immediate value to practicing veterinary professionals and directly contributes to evidence based clinical decision-making.

https://www.veterinaryevidence.org/

RCVS Knowledge is a registered Charity No. 230886.

Registered as a Company limited by guarantee in England and Wales No. 598443.

Registered Office: Belgravia House, 62-64 Horseferry Road, London SW1P 2AF

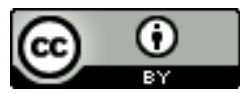

This work is licensed under a Creative Commons Attribution 4.0 International License 